\section{Mechanical and Durability Properties of Recycled Aggregate Concrete}

\section{Propriedades mecânicas e durabilidade de concretos com agregado reciclado}

\footnotetext{
${ }^{1}$ Federal University of São Carlos (UFSCar), Department of Civil Engineering, Via Washington Luís, km 235, 13565905, São Paulo, São Carlos, Brazil.

${ }^{2}$ University of Brasilia (UnB), Departament of Civil and Environmental Engineering, Campus Darcy Ribeiro, 70.910900, Federal District, Brasilia, Brazil.

e-mail: carol_nanya@yahoo.com.br, carolina.nanya@gmail.com,fgiannotti@ufscar.br, valdirenemaria@unb.br
}

\begin{abstract}
This paper investigates how the use of construction and demolition waste can affect the durability and affect the mechanical performance of concrete. tests such as compressive strength, tensile strength by diametral compression and modulus of elasticity were performed. Regarding durability, tests such as water immersion, void content and specific mass, water absorption by capillarity, electrical resistivity, the penetration depth of chloride ions, accelerated carbonation and a test evaluating the synergic effect of carbon dioxide and chloride ion penetration were performed. The coarse natural aggregate was replaced with coarse recycled aggregate in concrete mixes at the following ratios: $30 \%, 50 \%, 70 \%$, and 100\%. The results indicate that the parameters of the concrete produced with recycled aggregate, especially up to $50 \%$ replacement level, meet the concrete quality requirements, regarding the mechanical properties and durability.
\end{abstract}

Keywords: Civil Construction Residue. Concrete. Electrical Resistivity. Chloride Ions. Accelerated Carbonation.

\section{RESUMO}

Este documento investiga como o uso de resíduos de construção e demolição pode afetar a durabilidade e o desempenho mecânico do concreto. Testes como resistência à compressão, resistência à tração por compressão diametral e módulo de elasticidade foram realizados. Em relação à durabilidade, foram realizados ensaios como absorção de água por imersão, índice de vazios e massa específica, absorção de água por capilaridade, resistividade elétrica, profundidade de penetração de íons cloreto, carbonatação acelerada e avaliação do efeito combinado da penetração de dióxido de carbono e íons cloreto. $\mathrm{O}$ agregado natural foi substituído pelo agregado reciclado nas seguintes proporções: $30 \%, 50 \%, 70 \%$ e $100 \%$. Os resultados indicam que os concretos produzidos com agregado reciclado, especialmente até $50 \%$ de substituição, atendem aos requisitos de qualidade do concreto estrutural, no que diz respeito às propriedades mecânicas e durabilidade.

Palavras-chave: Resíduos da Construção Civil. Concreto. Resistividade Elétrica. Íons Cloreto. Carbonatação Acelerada.

\section{INTRODUCTION}

The economic development and the growing urbanization process has been causing serious damage to the environment and jeopardizing sustainability. The consumption of natural materials grows proportional to economic and population growth so that the demand for producing large volumes of materials requires a large-scale extraction of raw materials. Exploitation of resources, particularly nonrenewable resources, by the construction industry generates millions of tons of construction waste every year. These materials could and should be reused in new constructions; however, countries that do not have waste management and processing plans for such materials, direct them to landfills [38]. 
The magnitude of the problem is such that for annual consumption of 37.5 billion tons of aggregates [14] about 3 billion tons of construction wastes are generated [2]. According to data from the United States Environmental Protection Agency (EPA), approximately 548 million tons of construction and demolition waste are generated annually in the United States, about 830 million tons in the European Union, 200 million tons of concrete waste in China, 29 million tons in Taiwan and Hong Kong, totaling 1593 million tons of construction and demolition waste [44, 48, 49].

This large amount of waste impacts several sectors. Regarding environmental impacts, sustainability issues are a major concern today, since a large amount of natural resources is needed to produce materials such as concrete [25]. Recycling of waste has several potential advantages from the viewpoint of sustainability [39], and the first and most visible of these environmental contributions would be the preservation of natural resources, replaced by waste, extending the useful lives of natural reserves and reducing the destruction of the landscape, fauna, and flora [22]. Another issue that must be considered is $\mathrm{CO}_{2}$ emissions and energy consumption since the concrete industry, especially Portland cement, is known to contribute significantly to environmental damage and $\mathrm{CO}_{2}$ emissions [25].

From the economic viewpoint, in addition to the increasing transportation costs, the competitiveness of the economy provided by the recycling of building materials should be considered [45] as well since it may reduce the environmental protection costs by generating value from a product that was formerly an expense [22]. In a case study by Wijayasundata, Mendis and Crawford [48] using concrete with recycled aggregate was considered financially feasible with positive aspects compared to the production of conventional concrete due to decreasing costs of environmental protection and transportation of waste materials to the appropriate locations.

Many countries that understood the magnitude of the problems associated with the large-scale use of raw materials by the construction sector, have established policies and regulations to stimulate using recycled aggregate for producing concrete, such as China, Hong Kong, Germany, Japan, Portugal, Spain, United Kingdom, Australia, New Zealand, among others [2].

Unlike other countries, the Brazilian technical standards allow the use of recycled aggregate only in non-structural concrete (NBR 15116:2004) even though several studies have shown that the requirements for mechanical resistance are met satisfactorily [3, 19, 23, 27-29].

In recycled aggregate concrete, the loss in mechanical strength and modulus of elasticity can be attributed, among other factors, to the presence of the mortar adhered to the recycled aggregate, resulting in higher water absorption and lower specific mass. The interface transition zone between the new mortar and the aggregate is characterized as a fragile zone due to the poorer quality of the attached mortar in the recycled aggregates in comparison with that of the new mortar [3,4]. Regarding durability, this material lower performance may be associated with the inferior quality of construction and demolition waste, due to the presence of numerous cracks and pores observed in the aggregate, making it more permeable [30, 33, 43]. Nevertheless, the values obtained in the studies so far, show that partial replacement of the natural aggregate is possible, depending on the environment in which the material is inserted.

The compressive strength of concrete with recycled aggregate had been shown to decrease between $20 \%$ and $45 \%$ compared to conventional concrete, for the $25 \%$ and $100 \%$ replacement levels, respectively, considering the same parameters (mixture procedure, curing conditions, resistance class) [36]. However, in research that proposed a mixing method in which the cement and the recycled aggregate were added 20 minutes before the fine aggregate, coarse natural aggregate and superplasticizer, showed an improvement in the compressive strength for older ages (91 days) [26].

Additionally, the modulus of elasticity of concrete produced with recycled aggregate has shown a decreasing trend compared to conventional concrete. However, there is a study in the literature stating that it is possible to achieve a performance equivalent to conventional concrete simply by adjusting the w/c ratio [25], a concept applied to concrete produced with both coarse and fine recycled aggregate [37]. There are indications that by employing the "new mixing method" consisting of a pretreatment of the recycled aggregate with sodium silicate and active silica, the modulus of elasticity of concrete with $30 \%$ substitution of coarse recycled aggregate would be similar to conventional concrete [10]. The modulus of elasticity has been reported to decrease by approximately $40 \%$ for a $100 \%$ replacement rate of natural with coarse recycled aggregates [12], but it must be emphasized that for coarse recycled aggregate from pre-molded concrete structures, this reduction is about $11 \%$ [40].

Among the factors influencing the mechanical properties of concrete with recycled aggregate is the replacement content of the recycled aggregate [7, 15, 23, 32, 43]; changing the mixing procedures [10, 17, 42, 43]; type of recycled aggregate [3, 12, 36, 43, 50], and, aggregate porosity [5]. 
The study on the incorporation of alternative materials should not be limited to the determination of their mechanical properties [16]. The concrete mixture performance also depends on the parameters related to material durability [37]. Some studies have already identified that the concrete produced with recycled aggregate can present a performance that meets the useful life specified in the projects $[13,38,39,46]$. Several tests can be used to estimate the durability of the concrete structures, such as the electrical resistivity test. It is a non-destructive method that provides important data on the microstructure of cementitious materials, characterizing the degree of difficulty for ion mobility in the concrete, which would be related to properties such as permeability, pore diffusion, and connectivity, parameters related to durability [27].

In general, concretes with recycled aggregate have lower electrical resistance than conventional concretes. Studies in the literature indicate a decrease in resistivity of about 15\%, 34\%, 38\% and 50\% for concretes with the recycled aggregate replacement of $25 \%, 50 \%, 75 \%$, and $100 \%$ respectively $[49,50]$ considering coarse aggregates replacement. Several factors affect concrete electrical resistivity and may be related to concrete characteristics (w/c ratio, aggregate type and quantity, cement consumption, presence of mineral and chemical additives, cement hydration degree) [1, 8, 29, 40], environmental characteristics (temperature, relative humidity) [34], and the action of aggressive agents (chloride ions, $\mathrm{CO}_{2}$, among others) [34]. Also, the chloride penetration resistance of this material is lower than that of conventional concrete [40] since chloride ion penetration increased as the percentage of recycled aggregate increased as well [30].

Concrete with coarse recycled aggregate at 50\% and 100\% replacement levels showed $44 \%$ and $215 \%$ increase of chloride content [25], and about $16 \%$ and $39 \%$ increasing diffusion coefficients compared to the reference concrete [31]. However, for both conventional and recycled aggregate concretes, up to $20 \%$ reduction of chloride diffusion coefficients was observed with advancing age, which can be attributed to the cement hydration process, which, consequently, reduces concrete pore volume [31].

In addition, the literature shows that using coarse recycled aggregate in concrete lowers the resistance to the carbon dioxide action compared to reference concrete [16]. The increasing replacement percentage with aggregate greatly affects the carbon dioxide diffusion in concretes while, in the literature, increases of $18 \%, 47 \%, 60 \%$, and $73 \%$ have been reported for the $25 \%, 50 \%, 75 \%$ and $100 \%$ replacement percentages of concretes produced with fine and coarse recycled aggregates [39].

The magnitude of the accelerated carbonation front depends on numerous factors related to the use of the recycled aggregate, such as permeability [15], the recycled aggregate replacement rate [25, 32, 38, 39]; w/c ratio [39]; different curing conditions [11]; type and origin of the recycled aggregate [18]; highlighting the aggregate recycled from high-performance concrete, which tends to create a stronger link between the matrix and the aggregate [31]; and the use of superplasticizers [9] that allow using less water in the mixture.

As concrete structures are subjected to several simultaneous degradation mechanisms that, through a synergistic effect, accelerate the deterioration process, it is necessary to contemplate this action combined with that of the aggressive agents. Thus, in this study, the combined action of carbon dioxide and chloride ions on concrete was considered to achieve a better exposure simulation of concrete structures to deteriorating mechanisms.

In the literature, in terms of concrete with natural aggregate, the chloride concentrations increased by $33 \%$ at a depth near the reinforcement $(20 \mathrm{~mm})$ when submitted to the combined action of carbon dioxide and chloride ions compared to the isolated effect of chloride ions. Also, chloride migration coefficient increased from $0.83 \times 10^{-12}$ to $15.63 \times 10^{-12} \mathrm{~m}^{2} / \mathrm{s}$, after these same samples were submitted to the accelerated carbonation test [47]. This chloride increase was caused by the synergistic action of carbon dioxide and chloride ions since carbonated concrete has a decreasing chloride binding capacity, which affects the chloride flow. Besides that, the formation of microcracks, as a result of the concrete retraction process caused by carbonation, allows the chloride ions.

This work aims at evaluating the replacement of natural aggregate with recycled aggregate in concretes and assess their suitability for structural purposes. To determine the technical feasibility, the influence of the recycled aggregate on the concrete quality was evaluated via the mechanical properties (compressive strength, tensile strength, modulus of elasticity) and durability related properties (water absorption by immersion, water content by capillarity, electrical resistivity, the penetration depth of chloride ions, depth of carbonation). It is noteworthy that in terms of durability, both the isolated action of chloride ions and carbon dioxide and the joint action of these aggressive agents on the concrete were evaluated, which would be a first step in understanding their implications to the service life of reinforced concrete structures. 


\section{MATERIALS}

\subsection{Portland Cement}

Table 1 shows the used CP II - F 40 Portland cement (Type II in ASTM C150), with the physical and chemical parameters obtained via an X-ray fluorescence test.

Table 1: Physical and chemical parameters of Portland cement.

\begin{tabular}{|c|c|c|}
\hline \multicolumn{2}{|l|}{ PARAMETERS } & VALUES \\
\hline \multicolumn{2}{|c|}{ Specific mass (NBR NM 23:2001) } & $2.99 \mathrm{~g} / \mathrm{cm}^{3}$ \\
\hline \multicolumn{2}{|c|}{ Fineness index (NBR 11579:2012) } & $0.84 \%$ \\
\hline \multicolumn{2}{|c|}{ Normal consistency paste (NBR NM 65:2003) } & $\mathrm{a} / \mathrm{c}=0.40$ \\
\hline \multicolumn{2}{|c|}{ Initial set (NBR NM 43:2002) } & $1: 20 \mathrm{~h}$ \\
\hline \multicolumn{2}{|c|}{ Final set (NBR NM 43:2002) } & $2: 10 \mathrm{~h}$ \\
\hline \multirow{3}{*}{$\begin{array}{l}\text { Compressive strength (MPa) (NBR } \\
\text { 5739:2011) }\end{array}$} & 3 days & 37.6 \\
\hline & 7 days & 40.6 \\
\hline & 28 days & 48.5 \\
\hline \multicolumn{2}{|l|}{$\mathrm{CaO}$} & $76.12 \%$ \\
\hline \multicolumn{2}{|l|}{$\mathrm{SiO}_{2}$} & $9.10 \%$ \\
\hline \multicolumn{2}{|l|}{$\mathrm{Fe}_{2} \mathrm{O}_{3}$} & $4.09 \%$ \\
\hline \multicolumn{2}{|l|}{$\mathrm{SO}_{3}$} & $2.73 \%$ \\
\hline \multicolumn{2}{|l|}{$\mathrm{Al}_{2} \mathrm{O}_{3}$} & $2.45 \%$ \\
\hline \multicolumn{2}{|l|}{$\mathrm{MgO}$} & $2.34 \%$ \\
\hline \multicolumn{2}{|l|}{$\mathrm{K}_{2} \mathrm{O}$} & $1.90 \%$ \\
\hline \multicolumn{2}{|l|}{$\mathrm{TiO}_{2}$} & $0.49 \%$ \\
\hline \multicolumn{2}{|l|}{$\mathrm{SrO}$} & $0.48 \%$ \\
\hline \multicolumn{2}{|l|}{$\mathrm{MnO}$} & $0.06 \%$ \\
\hline
\end{tabular}

\subsection{Natural fine aggregate}

The used natural aggregate was quartz sand, with $4.75 \mathrm{~mm}$ maximum diameter and 2.27 fineness modulus. The granulometric distribution curve is represented in Figure 1.

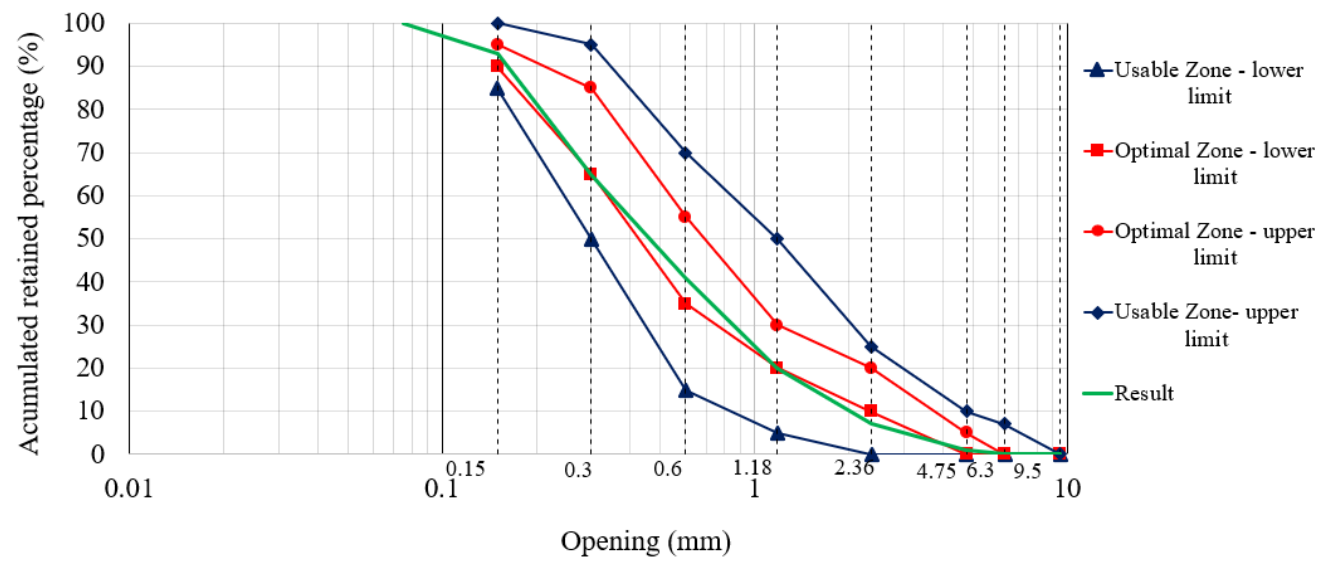

Figure 1: Granulometry of fine aggregate.

\subsection{Natural coarse aggregate}

To obtain the maximum compactness between the coarse basaltic aggregates, the composition of natural aggregates was determined as $70 \%$ with $19.0 \mathrm{~mm}$ maximum diameter $\left(\mathrm{D}_{\text {máx }}\right)$ and fineness modulus of 6,69 and $30 \%$ with $12.5 \mathrm{~mm} \mathrm{D}_{\text {máx }}$ and fineness modulus of 6,04. The grain distribution analysis (Figure 2) indicated a fineness modulus of 6.45. The physical parameters of the natural coarse aggregates are shown in Table 2. 


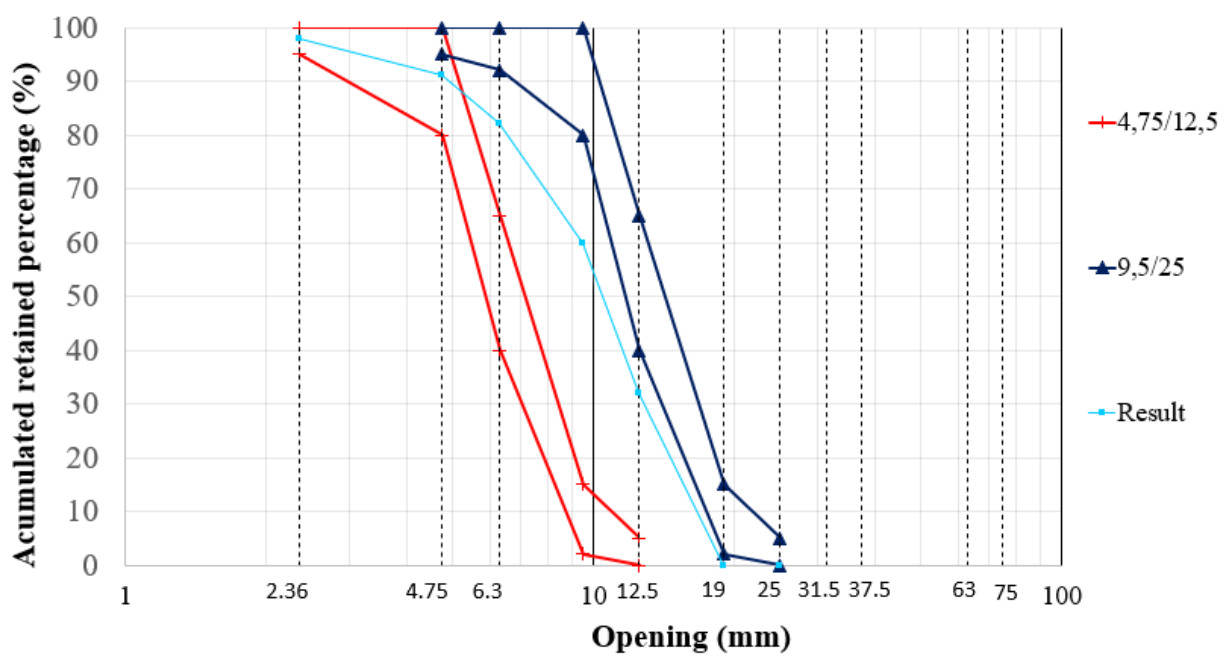

Figure 2: Granulometry of the natural coarse aggregates.

Table 2: Physical properties of the coarse aggregates.

\begin{tabular}{c|c} 
PARAMETERS & OBTAINED VALUES \\
\hline Specific mass of the dry aggregate $\left(\mathrm{g} / \mathrm{cm}^{3}\right)(\mathrm{NBR} N M$ 53:2009) & 2.79 \\
\hline Specific mass of the aggregate in the saturated dry surface condition $\left(\mathrm{g} / \mathrm{cm}^{3}\right)(\mathrm{NBR}$ NM 53:2009) & 2.80 \\
\hline Apparent specific mass $\left(\mathrm{g} / \mathrm{cm}^{3}\right)(\mathrm{NBR}$ NM 53:2009) & 2.82 \\
\hline Water absorption $(\%)(\mathrm{NBR} N M$ 53:2009) & 0.30 \\
\hline Unit mass of natural gravel composition $\left(\mathrm{g} / \mathrm{cm}^{3}\right)(\mathrm{NBR}$ NM 45:2006) & 1.44 \\
\hline
\end{tabular}

\subsection{Coarse recycled aggregate}

The coarse fraction of the recycled aggregate was used as a partial and total replacement for the natural basaltic aggregate $(0 \%, 30 \%, 50 \%, 70 \%$, and $100 \%$, by volume) in the concrete production. The natural aggregate was replaced with the recycled aggregate according to the percentage retained in each sieve in the granulometric distribution of the natural aggregate.

The recycled aggregates (Figure 3) were collected from a Recycling Plant in Brasília / DF. The grain distribution analysis of the materials indicated a $D_{\text {máx }}$ of $25.0 \mathrm{~mm}$ with fineness modulus of 7.03 (Figure 3a) and $\mathrm{D}_{\text {máx }}$ of $9.5 \mathrm{~mm}$ with fineness modulus of 4.74 (Figure $3 \mathrm{~b}$ ). The physical parameters of the recycled aggregate is demonstrated at Table 3 .
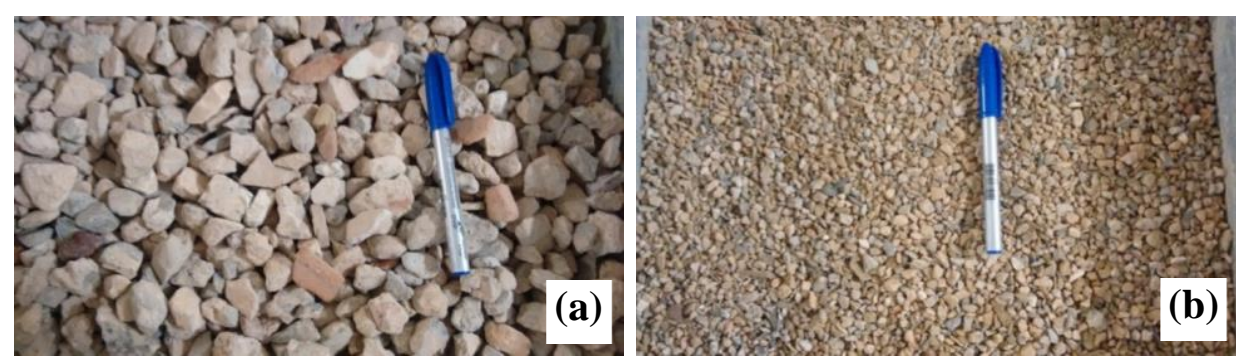

Figure 3: Recycled coarse aggregates a) $D_{\max }$ of $25.0 \mathrm{~mm}$ e b) $D_{\max }$ of $9.5 \mathrm{~mm}$. 
Table 3: Physical parameters of the recycled aggregate.

\begin{tabular}{|c|c|c|}
\hline MATERIAL & PARAMETERS & VALUES \\
\hline \multirow{5}{*}{$\begin{array}{l}\text { Recycled gravel } \\
\mathrm{D}_{\text {máx }}=25.0 \mathrm{~mm}\end{array}$} & Specific mass of the dry aggregate $\left(\mathrm{g} / \mathrm{cm}^{3}\right)($ NBR NM 53:2009) & 2.35 \\
\hline & $\begin{array}{l}\text { Specific mass of the aggregate in the saturated dry surface condition } \\
\qquad\left(\mathrm{g} / \mathrm{cm}^{3}\right)(\text { NBR NM 53:2009) }\end{array}$ & 2.49 \\
\hline & Apparent specific mass $\left(\mathrm{g} / \mathrm{cm}^{3}\right)(\mathrm{NBR}$ NM 53:2009) & 2.72 \\
\hline & Unit mass $\left(\mathrm{kg} / \mathrm{m}^{3}\right)(\mathrm{NBR} N M$ 45:2006) & 1441.40 \\
\hline & Water absorption (\%) (NBR NM 53:2009) & 5.85 \\
\hline \multirow{4}{*}{$\begin{array}{l}\text { Recycled gravel } \\
D_{\text {máx }}=9.5 \mathrm{~mm}\end{array}$} & Mass specific of the dry aggregate $\left(\mathrm{g} / \mathrm{cm}^{3}\right)(\mathrm{NBR}$ NM 53:2009) & 2.45 \\
\hline & $\begin{array}{l}\text { Specific mass of the aggregate in the saturated dry surface condition } \\
\qquad\left(\mathrm{g} / \mathrm{cm}^{3}\right)(\mathrm{NBR} N M \text { 53:2009) }\end{array}$ & 2.55 \\
\hline & Apparent specific mass $\left(\mathrm{g} / \mathrm{cm}^{3}\right)($ NBR NM 53:2009) & 2.78 \\
\hline & Water absorption (\%) (NBR NM 53:2009) & 5.22 \\
\hline
\end{tabular}

\subsection{Additive}

The dosing of the concretes used a superplasticizer additive based on modified polycarboxylic ether.

\subsection{Concrete production}

Five concrete samples were produced with different replacement rates: 0\% (reference concrete, REF), 30\% (30RCC), 50\% (50RCC), 70\% (70RCC) and 100\%, based on volume. The percentage replaced was defined by the mass fraction retained in each sieve of the granulometric characterization test conducted to determine the natural gravel composition. In the concrete dosage, the mortar content was $54 \%$ and the consistency used for all samples was set at $100 \pm 10 \mathrm{~mm}$.

A superplasticizer additive was used to maintain the consistency at $100 \pm 10 \mathrm{~mm}$. To compensate the water absorption of the recycled aggregate (NBR NM 53: 2003), additional water was considered, so that the effective w/c ratio of samples containing the recycled aggregate was higher, as shown in Table 4.

The recycled aggregates were wetted for 20 minutes because this material absorbs more than $80 \%$ of its absorption capacity during this interval. Water was added until the aggregate surface was totally covered [17, 23, 27] Subsequently, all materials were added to a concrete mixer: natural aggregate, sand, cement, remaining water, and superplasticizer additive. The concrete samples were kept in a humid chamber until the tests were performed.

The w/c ration was presented in two columns in order to show what would be the a/c ratio if we consider the water absorption of the recycled aggregate (w/c effective ratio) and the $\mathrm{a} / \mathrm{c}$ ratio used in the concrete dosage (w/c ratio).

Table 4: Reference concrete (REF) and concrete with recycled aggregate (30RCC, 50RCC, 70RCC, and 100RCC).

\begin{tabular}{c|c|c|c|c|c|c|c|c|c|c}
\hline \multicolumn{10}{c}{ CONCRETE COMPOSITION } \\
\hline Trace & $\begin{array}{c}\text { Recycled } \\
\text { aggregate } \\
\text { content }\end{array}$ & Cement & Sand & $\begin{array}{c}\text { Recycled } \\
\text { aggregate }\end{array}$ & Gravel & $\begin{array}{c}\text { SP } \\
\text { additive } \\
(\%)\end{array}$ & $\begin{array}{c}\text { w/c } \\
\text { ratio }\end{array}$ & $\begin{array}{c}\text { w/c } \\
\text { effective } \\
\text { ratio }\end{array}$ & $\begin{array}{c}\text { Specific } \\
\text { mass } \\
\left(\mathrm{g} / \mathrm{cm}^{3}\right)\end{array}$ & $\begin{array}{c}\text { Cement con- } \\
\text { sumption } \\
\left(\mathrm{kg} / \mathrm{m}^{3}\right)\end{array}$ \\
\hline REF & $0 \%$ & 1 & 2.24 & -- & 2.76 & 0.31 & 0.55 & - & 2.3881 & 364.6 \\
\hline 30RCC & $30 \%$ & 1 & 2.24 & 0.76 & 1.93 & 0.17 & 0.55 & 0.59 & 2.3305 & 358.0 \\
\hline 50RCC & $50 \%$ & 1 & 2.24 & 1.26 & 1.38 & 0.39 & 0.55 & 0.62 & 2.2779 & 350.4 \\
\hline 70RCC & $70 \%$ & 1 & 2.24 & 1.77 & 0.83 & 0.21 & 0.55 & 0.65 & 2.3067 & 361.0 \\
\hline 100RCC & $100 \%$ & 1 & 2.24 & 2.53 & - & 0.43 & 0.55 & 0.70 & 2.2436 & 355.0 \\
\hline
\end{tabular}

\section{METHODOLOGY}

The performance tests were conducted in triplicate $(10 \times 20 \mathrm{~cm}$ cylindrical test specimens) for each age group. The tests performed and the methods used are summarized at Table 5. 
Table 5: Summary of the tests performed and methods used.

\begin{tabular}{|c|c|c|c|}
\hline \multicolumn{2}{|r|}{ TESTS } & \multirow{2}{*}{$\begin{array}{l}\text { METHODOLOGY } \\
\text { NBR 5739:2007 }\end{array}$} & AGE \\
\hline \multirow{5}{*}{$\begin{array}{l}\text { Mechanical and } \\
\text { physical evalua- } \\
\text { tion }\end{array}$} & Compressive strength & & $\begin{array}{c}7,14,28 \text { and } 91 \\
\text { days } \\
\end{array}$ \\
\hline & Tensile strength by diametrical compression & NBR 7222:2011 & 28 days \\
\hline & Modulus of elasticity & NBR 8522:2008 & 28 days \\
\hline & Water absorption by immersion & NBR 9779:2012 & 28 days \\
\hline & Water absorption by capillarity & NBR 9778:1987 & 28 days \\
\hline \multirow{5}{*}{$\begin{array}{l}\text { Durability as- } \\
\text { sessment }\end{array}$} & Volumetric electrical resistivity & $\begin{array}{l}\text { AASHTO TP119- } \\
15 \\
\end{array}$ & $\begin{array}{c}28,63 \text { and } 114 \\
\text { days }\end{array}$ \\
\hline & Surface electrical resistivity & ASTM G57-06 & $\begin{array}{c}28,63 \text { and } 114 \\
\text { days }\end{array}$ \\
\hline & $\begin{array}{l}\text { Penetration depth of chloride ions by drying and } \\
\text { wetting cycles }\end{array}$ & $\begin{array}{l}\text { Colorimetric with } \\
0.1 \mathrm{M} \mathrm{AgNO}_{3} \text { spray }\end{array}$ & $\begin{array}{c}28,63 \text { and } 91 \\
\text { days } \\
\end{array}$ \\
\hline & Depth of carbonation & ISO 1920-12 & 28 days \\
\hline & $\begin{array}{l}\text { Penetration depth of chlorides by drying and wet- } \\
\text { ting cycles after carbonation }\end{array}$ & $\begin{array}{l}\text { Colorimetric with } \\
0.1 \mathrm{M} \mathrm{AgNO}_{3} \text { spray }\end{array}$ & $\begin{array}{c}28,63 \text { and } 91 \\
\text { days }\end{array}$ \\
\hline
\end{tabular}

The penetration depth of the chloride ions was determined after the concrete specimens were submitted to the drying and wetting cycles in a solution containing chlorides. After wet curing of the cylindrical concrete specimens, the samples were kept in the laboratory for 4 days (drying stage), and then partially immersed solution containing $3.5 \% \mathrm{NaCl}$ for 3 days (wetting step). The solution was replaced every 15 days. The concrete specimens were submitted to these drying and wetting cycles until the test day (28 days corresponding to 4 cycles; 63 days, 9 cycles; and 91 days, 13 cycles). At the end of each time interval tested, the specimens were broken off by diametrical compression followed by spraying silver nitrate $\left(\mathrm{AgNO}_{3}\right)$ and $0.1 \mathrm{M}$ distilled water solution onto the concrete surface. The measurements were made using the scalimeter with adequate precision in nine different points, equidistant from each other, distributed on the sample faces.

The carbonation of the concretes was analyzed at 28 days. The experimental procedures consisted of submitting the concrete specimens to 14-day preconditioning to clear the pores filled with water during curing and stabilization of the internal moisture followed by exposition to an environment containing $3 \pm 0.5 \%$ $\mathrm{CO}_{2}$ by volume, at $27 \pm 2^{\circ} \mathrm{C}$ temperature, and $65 \% \pm 5 \%$ relative humidity. To perform the test, the concrete specimens were sprayed with a solution containing $1 \%$ phenolphthalein, $70 \%$ ethyl alcohol and $29 \%$ distilled water (ISO 1920-12).

To evaluate the combined action of carbonation and chloride ions, the specimens were initially exposed to accelerated carbonation for 28 days and subsequently submitted to watering and drying cycles in $3.5 \% \mathrm{NaCl}$ solution, for the intervals of 28,63 and 91 days.

The mechanical and physical evaluations were performed in all specimens (REF, 30RCC, 50RCC, 70RCC, 70RCC, and 100RCC), while the durability tests were performed only on the REF, 30RCC and 50RCC specimens, which had the best mechanical and physical performances.

In the durability tests, we analyzed concretes containing up to $50 \%$ recycled aggregate since a comprehensive survey developed by Akhtar and Sarmah [2] recommended an ideal replacement percentage between 30 and 50\% while current regulations, in general, establish a $30 \%$ replacement percentage of the natural by the recycled aggregate. 


\section{RESULTS}

\subsection{Mechanical properties}

\subsubsection{Compressive strength}

The compressive strength (meaning average values plus standard deviation) results after 7, 14, 28 and 91 days is illustrated in Figure 4. The compressive strength decreased as the recycled aggregate replacement percentage increased, with the lowest value obtained for the 100RCC concrete. On the other hand, the 30RCC and 50RCC specimens had similar compressive strength values at 14 and 28 days that decreased between $12 \%$ and $17 \%$ compared to the reference concrete.

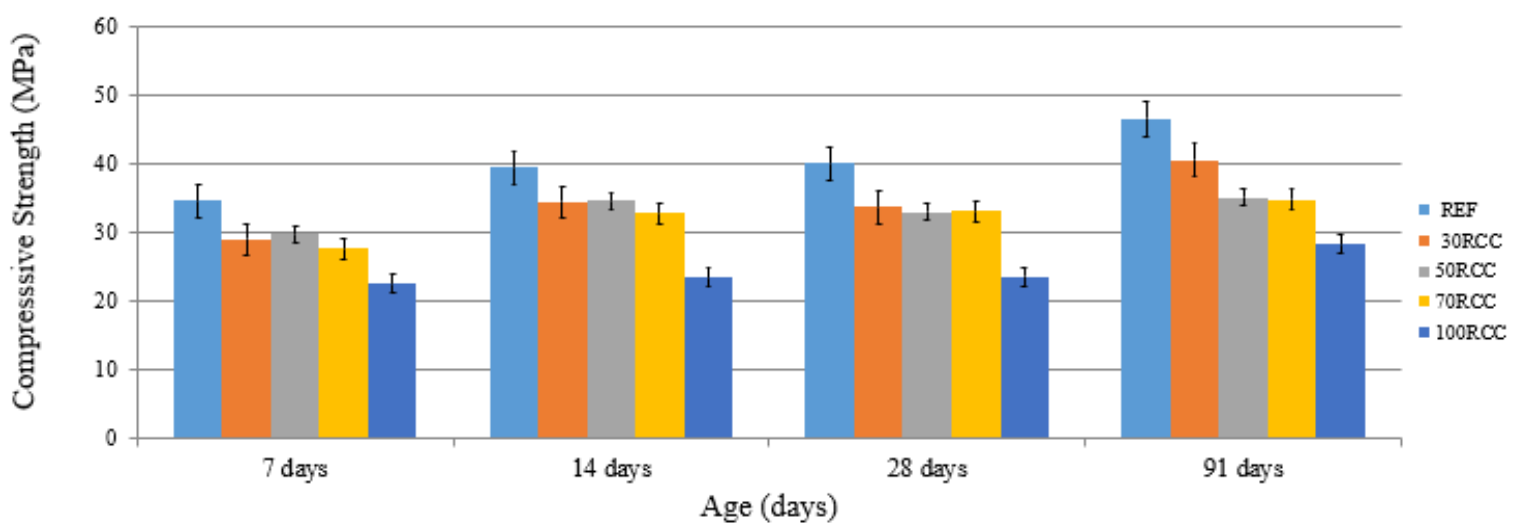

Figure 4: Compressive strength of concrete specimens.

The analysis of variance by ANOVA indicated that the replacement rate affected significantly ( $p$ $<0.05)$ the concrete compressive strength. The Duncan test grouped the 30RCC, 50RCC, and 70RCC specimens together, indicating a similar behavior, whereas the REF and 100RCC samples are in isolated groups. The total replacement of the natural coarse aggregate by the recycled one reduced the compressive strength significantly. On the other hand, replacing 30\%, 50\% and $70 \%$ of the natural with the recycled aggregate resulted in a mechanical performance compatible with concretes with structural function.

There is a consensus that a suitable replacement percentage would be up to $30 \%$, the limit for which the concrete mechanical properties are not very different from the conventional concrete. However, Bui, Satomi, and Takahashi [10] have adopted new methodologies in the concrete mixture and reported an acceptable replacement limit up to $50 \%$, without changing the concrete mechanical properties. In this new methodology only some sizes of the coarse aggregate were replaced $(7.93 \mathrm{~mm}, 6.73 \mathrm{~mm}$ and $5.60 \mathrm{~mm})$. But in this study it was used the conventional method, based on the replacement percentage of the entire of coarse aggregate mixture including all particle sizes in coarse aggregate particles. The correlation between the compressive strength and water absorption by immersion results for the concrete specimens is illustrated in Figure 5.

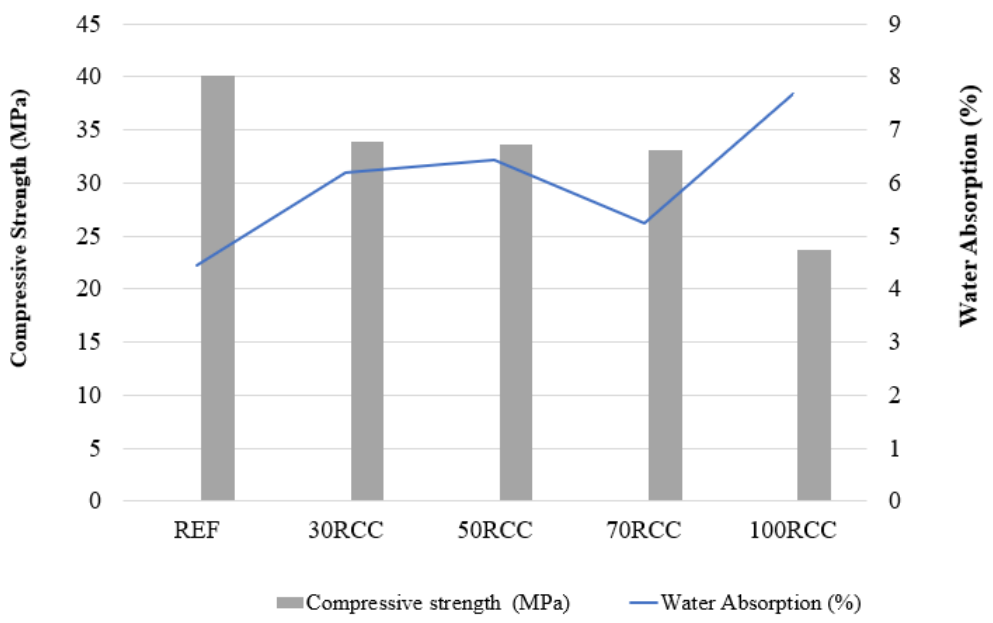

Figure 5: Relationship between compressive strength and water absorption of concrete specimens. 
According to Figure 5 the compressive strength and water absorption are inversely related. The reference concrete has higher compressive strength (40.2 MPa) and lower water absorption capacity (4.4\% - Table $6)$. As the recycled aggregate replacement ratio increases, the compressive strength decreases while water absorption capacity tends to increase. This result can be attributed to the greater porosity of the cementitious matrix that reduces the concrete resistance so that these properties display an antagonistic behavior.

Despite the fact that 70RCC has a higher percentage of replacement, the samples identified in this experiment showed low absorption. This can be attributed to the fact that it presents a smaller amount of mortar adhered to the coarse aggregates recycled in this portion. However, based on the classification of Helene (2000), analyzing the water absorption, only 100RCC concrete can be considered as deficient, the other concretes are classified as normal, highlighting that 50RCC concrete was at the limit between normal and deficient in relation to the quality of the material.

\subsubsection{Tensile strength by diametrical compression}

The tensile strength variation of concrete at 28 days is illustrated in Figure 6. Like the results obtained for the compressive strength, the reference concrete had the highest tensile strength value (4.0 MPa). Furthermore, statistically, the ANOVA method indicated that the percentage of recycled aggregate did not affect significantly the tensile strength by diametral compression of concrete.

A reduction of $27 \%$ was obtained for the $30 \mathrm{RCC}, 50 \mathrm{RCC}$, and $70 \mathrm{RCC}$ specimens compared to the reference concrete, and about $42 \%$ for the 100RCC sample. Likewise, Silva and Andrade [39] also observed the same trend, explaining it by the weak bond formed between the matrix of the hydrated cement and the recycled aggregate, due to the presence of adhered mortar.

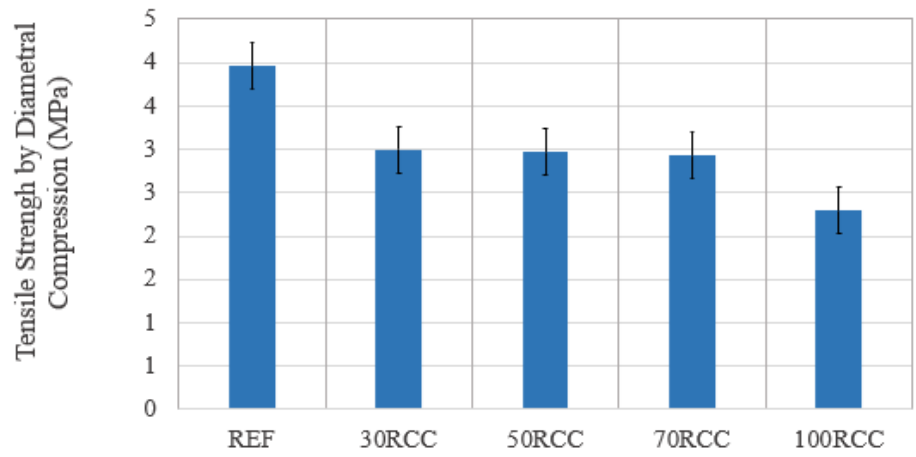

Figure 6: Tensile strength by diametral compression of concrete specimens at 28 days.

\subsubsection{Modulus of elasticity}

The 28-day modulus of elasticity results are illustrated in Figure 7. A decrease of about $25 \%$ is observed for the 30RCC, 50RCC and 70RCC samples compared to the reference concrete. The analysis of variance by ANOVA indicates that the recycled aggregate percentage in the sample affects the modulus of elasticity significantly (p-value was lower than 0.05 ) compared to the reference concrete.

This lower modulus of elasticity of the mixes in which the natural gravel was partially or totally replaced by construction and demolition waste can be attributed to the higher porosity and lower density of this material, compared with the basaltic gravel. In the 100RCC mix, there was a reduction of $40 \%$ in comparison with the concrete of reference (REF). These results are similar to those of Silva, Brito, and Dhir [37]. Better results were observed for concrete with recycled aggregate that originated from the crushing of highperformance concrete structures. 


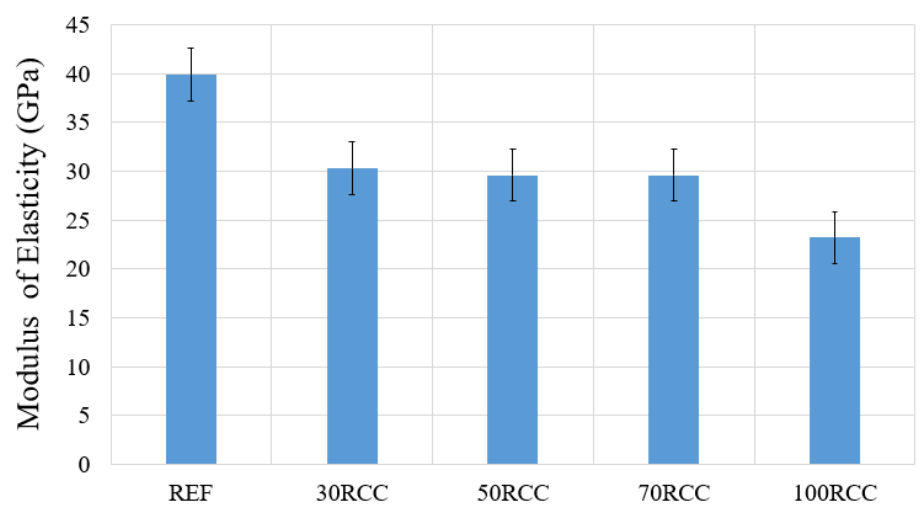

Figure 7: Modulus of elasticity of concrete specimens.

\subsection{Physical Properties}

As for the specific mass of fresh concrete, the concrete with recycled aggregate has slightly lower values (2.4 - 6.1\%) compared to the reference concrete. Shahidan et al. [35] also reached this same conclusion. The water absorption by immersion, void index and specific mass of concrete specimens is illustrated in Table 6 .

Table 6: Water absorption by immersion, void index and specific mass of concrete samples.

\begin{tabular}{c|c|c|c|c|c|c}
\hline \multirow{2}{*}{$\begin{array}{c}\text { CONCRETE } \\
\text { SPECIMENS }\end{array}$} & \multicolumn{3}{c}{ ABSORPTION (\%) } & MEAN & \multicolumn{4}{c}{ STANDARD DEVIATION (SD) } & \multicolumn{1}{c}{ MEAN. (\%) } & \multicolumn{3}{c}{ SD } & \multicolumn{1}{c}{ MEAN } & SD \\
\hline REF & 4.4 & 0.21 & 10.2 & 0.03 & 2.303 & 0.009 \\
\hline 30RCC & 6.0 & 0.30 & 14.0 & 0.04 & 2.215 & 0.012 \\
\hline 50RCC & 6.4 & 0.15 & 15.1 & 0.10 & 2.215 & 0.012 \\
\hline 70RCC & 5.2 & 0.11 & 12.6 & 0.09 & 2.206 & 0.004 \\
\hline 100RCC & 7.7 & 0.07 & 17.3 & 0.19 & 2.096 & 0.017 \\
\hline
\end{tabular}

The water absorption by immersion, void index, and specific mass tests indicated that the specimen specific mass decreased while the percentage of water absorption and void index increased up to $70 \%$ compared to the reference concrete. The results of water absorption by immersion, void index, and specific mass tests are shown in Table 6 . The results for the water absorption by capillarity tests is illustrated in Figure 8 .

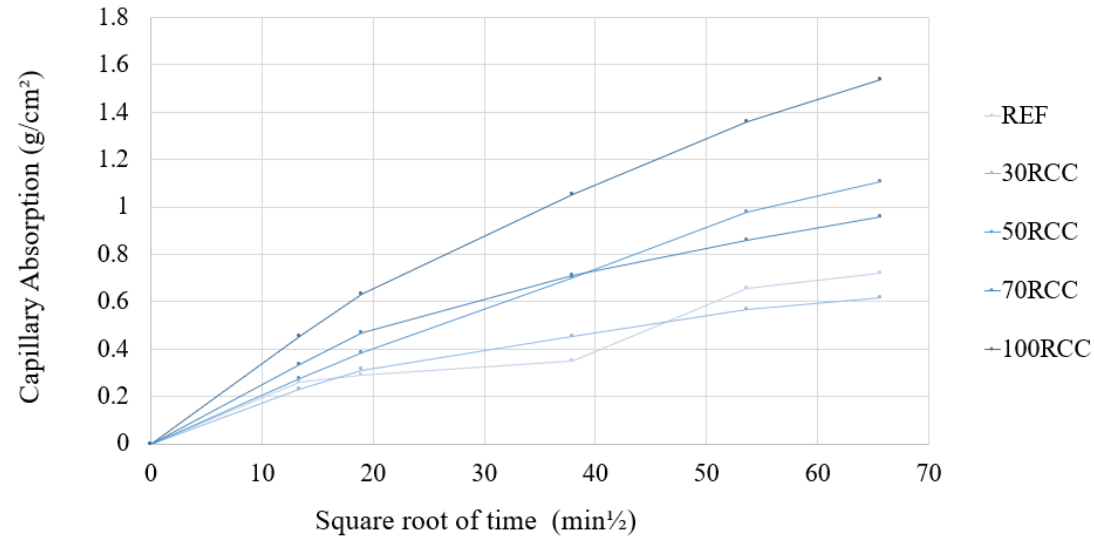

Figure 8: Water absorption by capillarity of concrete.

The capillary absorption test indicated an increase of about $100 \%$ in the water absorption percentage when the natural aggregate was totally replaced by the recycled aggregate. Likewise, Bravo et al. [9] reported an increase of about $86 \%$ in capillary absorption, when recycled aggregate was incorporated into the concrete. Figure 8 shows the values obtained in the capillary absorption tests for better visualization.

To characterize the tendency of the studied material to absorb and transmit water by capillarity and, consequently, the material susceptibility to the ingress of degradation agents, the sorptivity coefficients of the mixes were calculated. The incorporation percentage of the recycled aggregate affects significantly the ab- 
sorption capacity, resulting in $0.016 \mathrm{~g} / \mathrm{cm}^{2} \cdot \mathrm{min}^{0,5}$ and $0.021 \mathrm{~g} / \mathrm{cm}^{2} \cdot \mathrm{min}^{0,5}$ for the $50 \mathrm{RCC}$ and $100 \mathrm{RCC}$ samples, respectively, while the sorptivity coefficient was $0.009 \mathrm{~g} / \mathrm{cm}^{2} \cdot \mathrm{min}^{0,5}$ for the reference concrete. These higher sorptivity coefficients for the recycled aggregate concrete can be attributed to the higher intrinsic porosity of the recycled material and the different origin of the recycled aggregate. The capillary heights obtained in the capillary water absorption test for the REF, 70RCC and 100RCC concrete specimens are illustrated in

Figure 9.
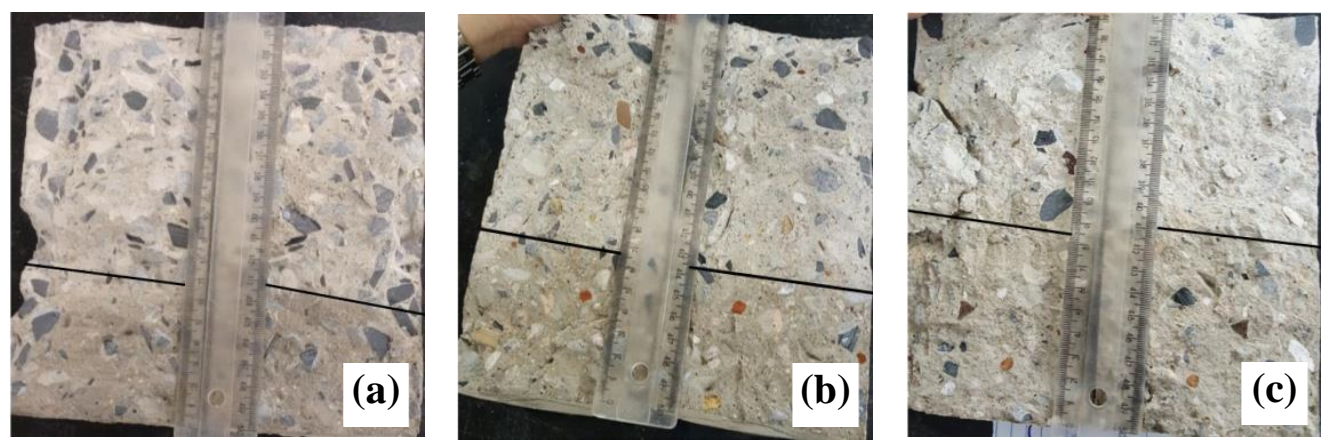

Figure 9: Capillary heights of the different specimens: a) REF, b) 70RCC e c) 100RCC.

\subsection{Durability assessment}

\subsubsection{Electrical resistivity}

The mean values obtained in the volumetric and surface electrical resistivity tests are illustrated in Figure 10 and Figure 11, respectively. The reference concrete presented higher resistivity values than the recycled aggregate concrete mixes, thus indicating a significant effect $(\mathrm{p}<0.05)$ of the replacement rate on the electrical resistivity of concrete. Additionally, the higher the replacement rate, the higher the electrical conductivity and, consequently, the lower the electrical resistivity, which has also been reported by Singh and Singh [40]. Santos [34] and Higuera et al. [20] attribute this result to the higher porosity of the recycled aggregate material and the greater amount of electrolytic solution in the concrete pores.

Regarding the relationship between the surface and volumetric electrical resistivity values, the results indicated that the surface electrical resistivity is about twice the volumetric electrical resistivity, which has also been reported by Spragg et al. [41] and Azzi and Costa [6].

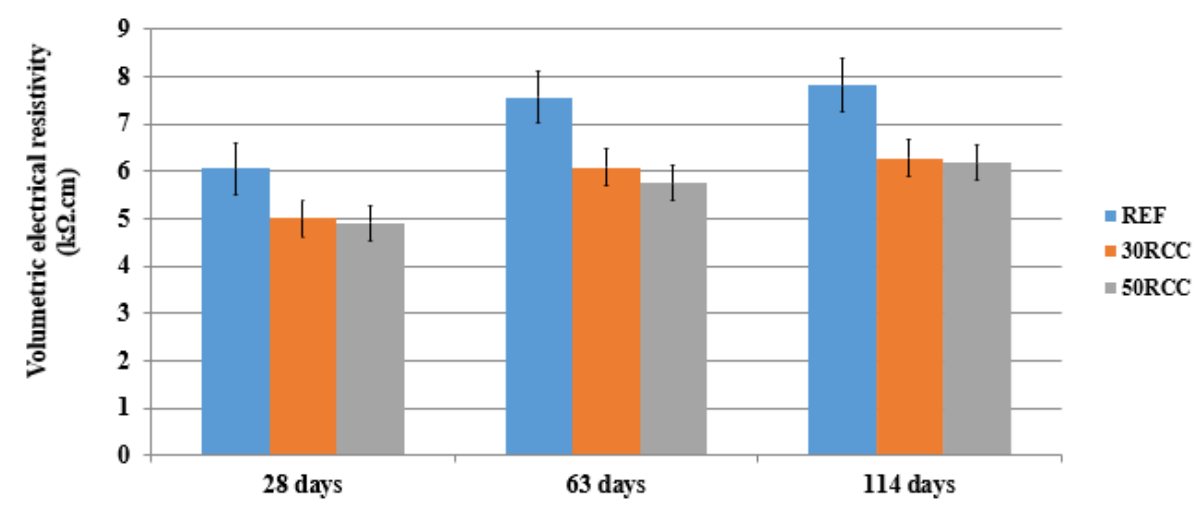

Figure 10: Volumetric electrical resistivity of the REF, 30RCC and 50RCC specimens, at 28, 63 and 114 days. 


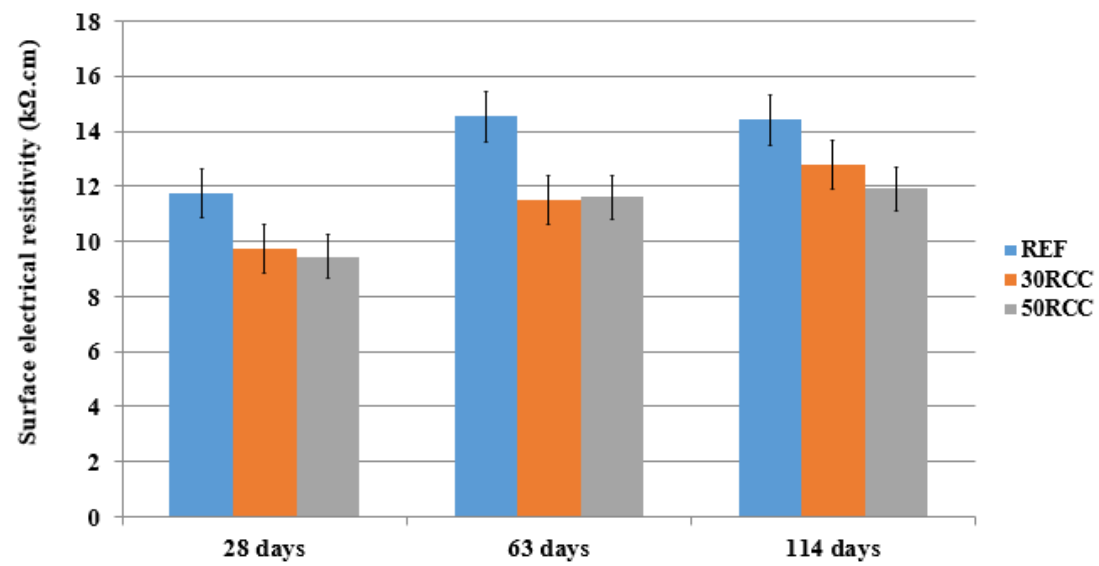

Figure 11: Surface electrical resistivity of the REF, 30RCC and 50RCC specimens, at 28, 63 and 114 days.

The results showed that concrete electrical resistivity increased over time due to hydration. During the cement hydration process, the formed compounds gradually fill in the voids initially occupied by the electrolyte and, therefore, the pore structure of the cementitious matrix changes, increasing the material resistivity. Table 7 and Table 8 show the classification of the concrete specimens according to the electrical resistivity values of the applicable standards.

Table 7: Classification of the concretes regarding penetration depth of chloride ions.

\begin{tabular}{c|c|c|c}
\hline \multirow{2}{*}{ Concrete } & \multicolumn{3}{c}{ VOLUMETRIC ELECTRICAL RESISTIVITY } \\
\cline { 2 - 4 } & \multicolumn{3}{|c}{ Standard AASHTO TP 119-15 } \\
\cline { 2 - 4 } & 28 days & 63 days & 114 days \\
\hline REF & Moderate & Moderate & Moderate \\
\hline 30RCC & Alto & Moderate & Moderate \\
\hline 50RCC & Alto & Moderate & Moderate \\
\hline
\end{tabular}

Table 8: Classification of concretes regarding the penetration depth of chloride ions and the risk of corrosion.

\begin{tabular}{cccccccccc}
\hline \multicolumn{8}{c}{ SURFACE ELECTRICAL RESISTIVITY } \\
\hline \multirow{2}{*}{ Concrete } & \multicolumn{7}{c}{ Standard AASHTO TP 119-15 } & \multicolumn{7}{c}{ Risk of Corrosion } \\
\cline { 2 - 10 } & 28 days & 63 days & 114 days & 28 days & 63 days & 114 days & 28 days & 63 days & 114 days \\
\cline { 2 - 11 } REF & Low & Low & Low & Moderate & Moderate & Moderate & Low & Low & Low \\
30RCC & Moderate & Low & Low & High & Moderate & Moderate & High & Low & Low \\
50RCC & Moderate & Low & Low & High & Moderate & Moderate & High & Low & Low \\
\hline
\end{tabular}

\subsubsection{Penetration depth of chloride ions}

The penetration depth of the chloride ions in the concrete mixes is illustrated in Figure 12. According to the results, the replacement rate affects the penetration depth of chloride ions, by increasing the susceptibility to the transport of aggressive agents. 


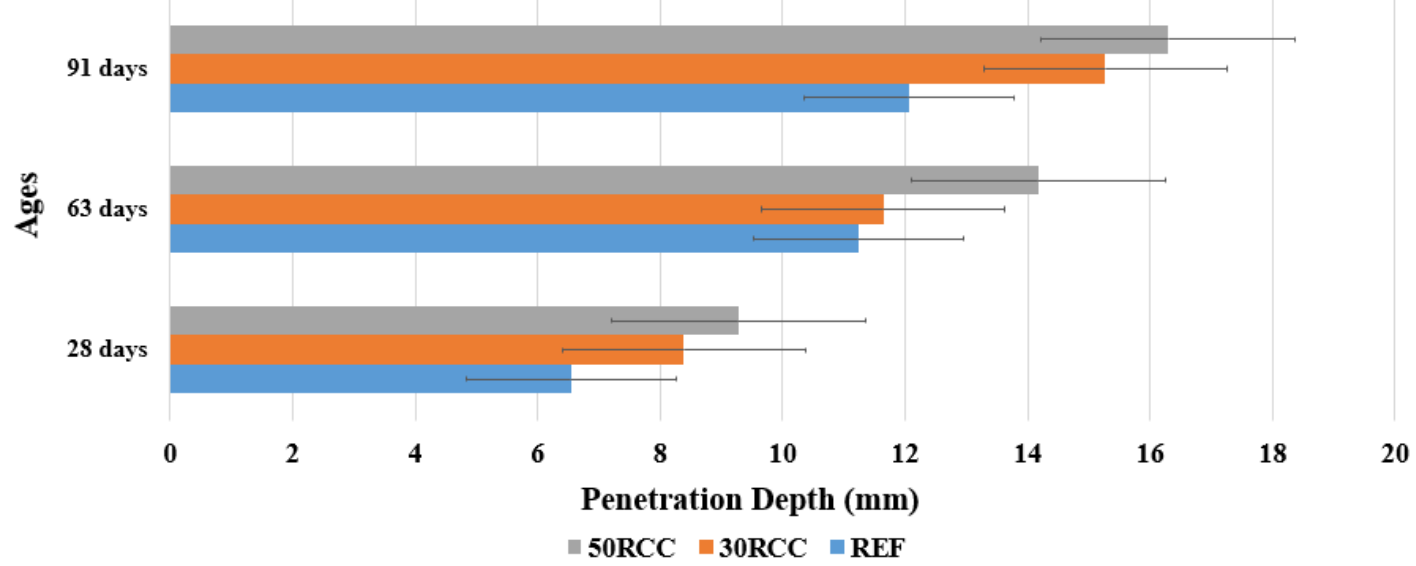

Figure 12: Penetration depth of chloride ions at 28, 63 and 91 days.

The analysis of variance by ANOVA shows that the recycled aggregate percentage affects significantly $(\mathrm{p}<0.05)$ the penetration depth of chloride ions. The Duncan test classified the REF, 30RCC and 50RCC specimens in different groups (01, 02 and 03, respectively). The average values obtained for 30RCC and 50RCC concretes are closer to each other than to the REF concrete, indicating that, although the recycled aggregate reduces the resistance to the action of chloride ions, the increasing replacement rate would not interfere proportionally with the values obtained.

Also, Figure 12 shows that the $30 \%$ replacement rate, despite having a lower resistance to the action of chloride ions, addresses the issue of durability and mechanical properties, as presented previously. Similarly, Limbachiya, Meddah, and Ouchagur [25] also reached this same conclusion in their studies.

\subsubsection{Depth of accelerated carbonation}

Additionally, the results show an increase of the carbonation depth for the recycled aggregate mixes compared to the reference concrete. The obtained concrete carbonation coefficients were 4.19; 5.45 and 5.49 $\mathrm{mm} / \mathrm{ano}^{0,5}$ for the reference (REF), 30RCC and 50RCC, respectively.

\subsubsection{Combined action of carbonation and chloride ions}

The penetration depth of chloride ions, in mm, is illustrated in Figure 13. The specimens had already been subjected to accelerated carbonation. It is observed that the penetration depth of chloride ions increases in the recycled aggregate specimens compared to the reference concrete, with values higher than those obtained for samples submitted only to the action of the chloride ions.

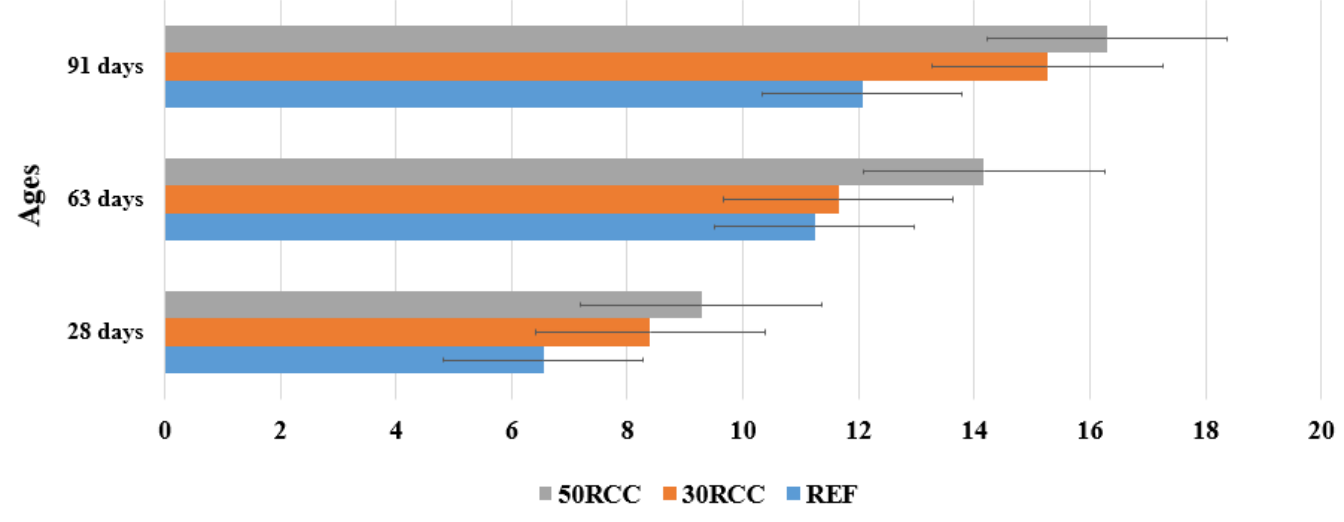

Figure 13: Penetration depth of the chloride ions after exposure to the $3.5 \% \mathrm{NaCl}$ solution (after being submitted to $\mathrm{CO}_{2}$ action).

The $p$-value $(p<0.05)$ by ANOVA shows that the replacement percentage affects significantly the penetration depth of chloride ions. The Duncan test grouped the concrete specimens in groups 01, 02 and 03 , respectively, at 28 days. Although the average penetration depth of chloride ions varied, the chloride ions never reached the concrete reinforcement in any of the studied samples, considering the minimum nominal 
cover of $02 \mathrm{~cm}$ as required in the Brazilian standards (NBR 6118:2014) for reinforced concrete structures. The results for the penetration depth of chloride ions of the mixes submitted only to chloride wetting/drying cycles and to the combined effect of carbonation and chloride ions, at 28,63 and 91 days are illustrated in Figure 14

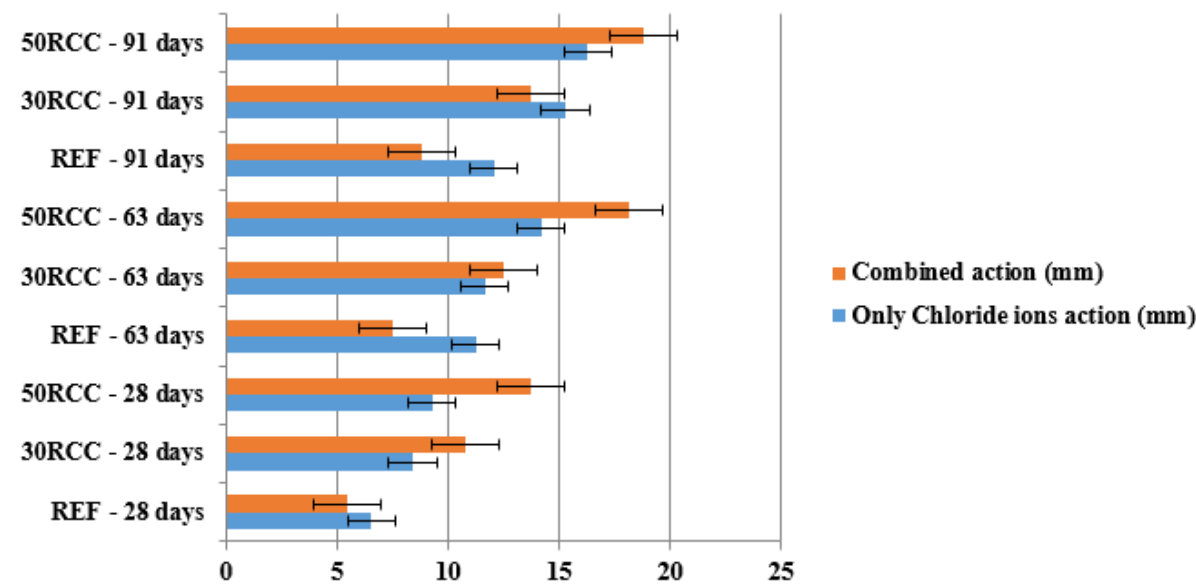

Figure 14: Penetration depth of chloride ions submitted only to chloride ions and to the combined effect of carbonation + chlorides (mm).

The deleterious effect of carbonation on concrete with recycled aggregate, which had more penetration fronts of chloride ions at all ages is illustrated in Figure 14. The combined effect is more deleterious in concrete with recycled aggregate since this type of material, because of the more porous nature, made it possible to fill the pores of the concrete through the process of carbonation, which enabled a greater capillary height of the chloride ions in the samples. It is necessary to highlight that the samples did not show penetration front and chloride ions at the top due to partial immersion in the $\mathrm{NaCl}$ solution. The chloride penetration fronts after spraying the silver nitrate solution at 91 days is illustrated in Figure 15.

(a)

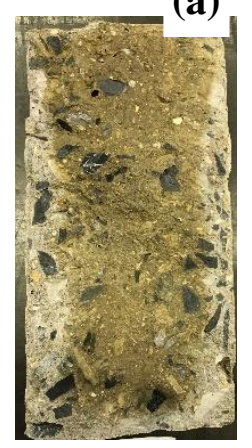

(b)

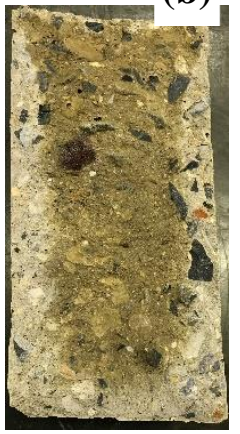

(c)

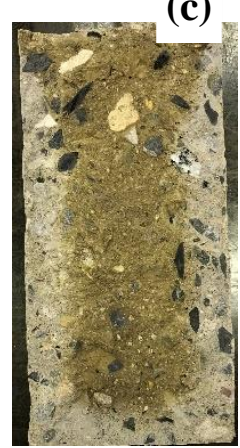

Figure 15: Chloride ion penetration at 91 days a) REF, b) 70RCC e c) 100RCC.

The higher chloride penetration was observed at 91 days (Figure 15). The colorimetric assay showed a higher chloride penetration in the 50RCC specimen compared to the others (REF, 30RCC). The greater penetration depths of chloride ions in specimens subjected to carbon dioxide action is attributed to the displacement of chloride ions from carbonate to non-carbonated regions induced by carbonation. Likewise, Yu et al. [51] obtained a maximum chloride concentration in the carbonation front of specimens subjected to the combined action of these aggressive agents.

The pore filling due to the formation of calcium carbonate may increase chloride ion penetration by capillarity. This would be an indication that carbonation facilitates chloride ions entering the concrete structure, increasing their penetration and intensifying reinforcement corrosion. 


\section{CONCLUSIONS}

The results of this study allow to conclude the following:

- Replacing the natural with recycled aggregate in concrete specimens affects the mechanical properties; it lowers compressive strength, tensile strength by diametral compression, and modulus of elasticity. However, as for the mechanical properties, it can be mentioned that the concrete $50 \%$ RCC and 70\% RCC showed similar results with regard to the mechanical properties, which means that with the incorporation of RCC in the concrete, even in high percentages of substitution of the natural aggregate, does not prejudice the resistance of the analyzed concrete;

- The replacement percentage greatly influences the physical properties of the produced concrete as clearly identified in the analyzed properties, water absorption by immersion, void index, specific mass, and capillary absorption;

- As for durability, it can be said that, although concretes with incorporation of recycled aggregate are less resistant, when subjected to the action of various aggressive agents (chloride and carbonation ions), the analyzed concretes present an adequate performance. Thus, considering the features 30RCC and 50RCC, it can be said that the use of concrete material with recycled aggregate is feasible even with a structural function, although there is no Brazilian standard that regulates the use of this material;

- Even when considering the action of more than one aggressive agent on the concrete (combined action of carbon dioxide and penetration of chloride ions), a very unfavorable scenario from the viewpoint of durability, the action front of the chloride ions would be less than the minimum thickness of the recommended cover layer for both natural and recycled aggregate concretes.

- It is possible to use the recycled aggregate from the standpoint of mechanical properties and durability, since the performance was adequate according to ABNT regulations, even when considering the combined effect of aggressive agents (carbon dioxide and chloride ions). However, a rigorous characterization and standardization of the recycled aggregate is necessary since this material can vary from region to region and even from one batch to another.

\section{ACKNOWLEDGEMENTS}

The authors are grateful to PPGCIV / UFSCar, UnB, as well as to Areal Bela Vista, Areia Lemos and Real Mix, for supplying the used materials. This research did not receive any specific grant from funding agencies in the public, commercial, or not-for-profit sectors.

\section{BIBLIOGRAPHY}

[1] ABREU, A.G, Efeito das adições minerais na resistividade elétrica de concretos convencionais, Dissertation of M. Sc, Federal University of Rio Grande do Sul (UFSC), Porto Alegre, RS, Brazil, 1998.

[2] AKHTAR, A., SARMAH, A.K., "Construction and demolition waste generation and properties of recycled aggregate concrete: A global perspective", https://doi.org/10.1016/j.jclepro.2018.03.085. Journal of Cleaner Production, v. 186, pp. 262-281, June 2018.

[3] ALEXANDRIDOU, C., ANGELOPOULOS, G.N., COUTELIERIS, F.A, "Mechanical and durability performance of concrete produced with recycled aggregates from Greek construction and demolition waste plants", https://doi.org/10.1016/j.jclepro.2017.12.081. Journal of Cleaner Production, v.176, pp. 745-757, March 2018.

[4] ANDREU, G., MIREN, E., "Experimental analysis of properties of high performance recycled aggregate concrete", https://doi.org/10.1016/j.conbuildmat.2013.11.054. Construction and building Materials, v.52, pp.227-235, Feb. 2016.

[5] ÂNGULO, S.C., Caracterização de agregados de resíduos de construção e demolição reciclados e a influência de suas características no comportamento de concretos, Thesis D.Sc., Polytechnic School of University of São Paulo, São Paulo, SP, Brazil, 2005.10.11606/T.3.2005.tde-18112005-155825

[6] AZZI, S.S., COSTA, J.M., "Comparação da resistividade elétrica superficial e volumétrica de concreto em cimento Portland" IV, Construindo, Belo Horizonte, http://www.fumec.br/revistas/construindo/article/view/5461/2960. v. 8, pp. 36-46, June 2017. 
[7] BAIRAGI, N.K., RAVANDE, K., PAREEK, V.K., "Behavior of concrete with different proportions of natural and recycled aggregates", Resources, https://doi.org/10.1016/0921-3449(93)90036-F. Conservation and Recycling, v.9, pp. 109-126, Aug. 1993.

[8] BRAMESHUBER, W., RAUPACH, M., "Non-destructive determination of the water content in the concrete cover using multiring-electrode". In: International Symposium Non-destructive Testing in Civil Engineering (NDT-CE), Berlin, Germain, 16-19, September 2003. https://www.ndt.net/article/ndtce03/pdf/order.htm

[9] BRAVO, M., BRITO, J., EVANGELISTA, L., et al. "Durability and shrinkage of concrete with CDW as recycled aggregates: Benefits from superplasticizer's incorporation and influence of CDW composition". Construction and Building Materials, v.168, pp. 818-830, April 2018. 10.1016/j.conbuildmat.2018.02.176

[10] BUI, N.K., SATOMI, T., TAKAHASHI, H., "Improvement of mechanical properties of recycled aggregate concrete based on a new combination method between recycled aggregate and natural aggregate", https://doi.org/10.1016/j.conbuildmat.2017.05.084. Construction and Building Materials, v.148, pp. 376-385, Sep. 2017.

[11] BUYLE-BODIN, F., ZAHARIEVA, H.," Influence of industrially produced recycled aggregates on flow properties of concrete", https://doi.org/10.1007/BF02483138. Materials and Structures, v.35, pp. 504-509, Sep. 2002.

[12] CABRAL, A.E.B., SCHALCH, V., DAL MOLIN, D.C.C., et al. "Determinação da influência do tipo de agregado reciclado de resíduo de construção e demolição sobre o módulo de deformação de concretos produzidos com agregados reciclados". http://www.scielo.br/scielo.php?script=sci_arttext\&pid=S1983-

41952008000200004\&lng=pt\&tlng=pt. In: IBRACON (Instituto Brasileiro do Concreto), pp. 171-192, São Paulo, SP, June 2008.

[13] DEBIEB, F., COURARD, L., KENAI; S., et al. "Mechanical and durability properties of concrete using contaminated recycled aggregates", https://doi.org/10.1016/j.cemconcomp.2010.03.004. Cement \& Concrete Composite, v.35, pp.421-426, July 2010.

[14] DING, T., XIAO, J., TAM, V.W.Y., “A closed-loop life cycle assessment of recycled aggregate concrete utilization in China", https://doi.org/10.1016/j.wasman.2016.05.031. Waste Management, v.56, pp. 367375, Oct. 2016.

[15] ETXEBERRIA, M., VÁZQUEZ, E., MARI, A., et al., "Influence of amount of recycled coarse aggregates and production process on properties of recycled aggregate concrete", https://doi.org/10.1016/j.cemconres.2007.02.002. Cement and Concrete Research, v.37, pp. 735-742, May 2007.

[16] EVANGELISTA, L., BRITO, J., "Durability performance of concrete made with fine recycled concrete aggregates", https://doi.org/10.1016/j.cemconcomp.2009.09.005. Cement \& Concrete Composites, v.32, pp.9-14, Jan. 2010.

[17] FERREIRA, L., BRITO, J., BARRA, M., "Influence of the pré-saturation of recycled coarse concrete aggregates on the mechanical strength and durability of structural concrete", Magazine of Concrete Research, v.42, pp. 617-627, Aug. 2011. 10.1680/macr.2011.63.8.617

[18] GOMES, M., BRITO, J., "Structural concrete with incorporation of coarse recycled concrete and ceramic aggregates: durability performance", https://doi.org/10.1617/s11527-008-9411-9. Materials and Structures, v.42, pp. 663-675, July 2008.

[19] GONÇALVEZ, R.D.C., Agregados reciclados de resíduos de concreto: Um novo material para dosagens estruturais, Dissertation of M.Sc., Engineer School of São Carlos, São Paulo, SP, Brazil, 2001.

10.11606/D.18.2016.tde-06052016-150748

[20] HELENE, P.R.L. Contribuição ao estudo da corrosão em armaduras de concreto armado. Thesis, Polytechnic School of University of São Paulo, São Paulo, SP, Brazil, 1993.

[21] HIGUERA, R.C., ARREDONDO, S., ALMARAL, J., et al. "Chloride corrosion of embedded reinforced steel on concrete elaborated from recycled coarse aggregates and supplementary cement materials". http://dx.doi.org/10.4067/S0718-50732013000100002. Revista Ingeniería de Construcción - RIC. Santiago, pp. 21-35, April 2013.

[22] JOHN, V.M., Reciclagem de resíduos na construção civil: Contribuição à metodologia de pesquisa e desenvolvimento, Thesis of D. Sc., Polytechnic School of University of São Paulo, São Paulo, SP, Brazil, 2000 . 
[23] LEITE, M.B., Avaliação de propriedades mecânicas de concretos produzidos com agregados reciclados de resíduos de construção e demolição, Thesis of D.Sc., Federal Universitu of Rio Grande do Sul, Porto Alegre, RS, Brazil, 2001.http://hdl.handle.net/10183/21839

[24] LIMBACHIYA, M.C., LLELAWAT, T., DHIR, R.K., "RCA Concrete: A study of properties in the fresh state, strength development and durability", ICE Manual of Construction Materials - Sustainable Construction: Use of Recycled Concrete Aggregate, July 2015.

https://www.icevirtuallibrary.com/doi/abs/10.1680/scuorca.27268.0020

[25] LIMBACHIYA, M., MEDDAH, M.S., OUCHAGOUR, Y., "Use of recycled concrete aggregate in fly ash concrete", https://doi.org/10.1016/j.conbuildmat.2011.07.023. Construction and Building Materials, v.27, pp. 439-449, Feb. 2012.

[26] MABEL, C.M.A., CAPUZZO, V.M.S. Avaliação da durabilidade de concretos produzidos com agregados de resíduo de concreto utilizando a abordagem de mistura dois estágios, Revista Matéria, v. 25, n.1, Abr. 2019.

[27] MCCARTER, W.J., STARRS, G., CHRISP, T.M., "Electrical conductivity, diffusion, and permeability of Portland cement-based mortars", https://doi.org/10.1016/S0008-8846(00)00281-7. Cement and Concrete Research, v.30, pp. 1395-1400, Sep. 2000.

[28] MORETTI, J.P., Estudo de viabilidade técnica da utilização da ACBC e do RCC na composição de concretos, Dissertation of MSc., Federal University of São Carlos, São Carlos, SP, Brazil,

2014.https://repositorio.ufscar.br/handle/ufscar/4692

[29] NEVILLE, A.M., Properties of concrete. Pearson Education Limited, Inc: England, 5th Edition, 2013.

[30] OLORUNSOGO, F.T., PADAYACHEE, N., "Performance of recycled aggregate concrete monitored by durability indexes", https://doi.org/10.1016/S0008-8846(01)00653-6. Cement and Concrete Research, v.32, pp. 179-185, Feb. 2002.

[31] PEDRO, D., BRITO, J., EVANGELISTA, L., "Structural concrete with simultaneous incorporation of fine and coarse recycled concrete aggregates: Mechanical, durability and long-term properties",

ttps://doi.org/10.1016/j.conbuildmat.2017.07.215. Construction and Building Materials, v.154, pp. 294-309, Nov. 2017. $\mathrm{h}$

[32] POON, C., CHAN, D., "The use of recycled aggregate in concrete in Hong Kong. Resources", https://doi.org/10.1016/j.resconrec.2006.06.005. Conservation \& Recycling, v. 50, pp. 293-305, May 2007.

[33] POON, C. S., KOU, S.C., "Enhancing the durability properties of concrete prepared with the coarse recycled aggregate", https://doi.org/10.1016/j.conbuildmat.2012.02.032. Construction and Building Materials, v. 32, pp. 69-76, Oct. 2012.

[34] SANTOS, L., Avaliação da resistividade elétrica do concreto como parâmetro para a previsão da iniciação da corrosão induzida por cloretos em estruturas de concreto. Dissertation of M.Sc., University of Brasilia, Brasília, Brazil, 2006. https://repositorio.unb.br/handle/10482/5188

[35] SHAHIDAN, S., AZMI, M.A.M., KUPUSAMY, K., et al. "Utilizing construction and demolition (C\&D) waste as Recycled Aggregates (RA) in Concrete", https://doi.org/10.1016/j.proeng.2017.01.255. Procedia Engineering, v. 17, pp. 1028-1035.

[36] SILVA, R.V., BRITO, J., DHIR, R.K., "Properties and composition of recycled aggregates from construction and demolition waste suitable for concrete production",

https://doi.org/10.1016/j.conbuildmat.2014.04.117. Construction and Building Materials, v.65, pp.201-217, Aug. 2014.

[37] SILVA, R.V., BRITO, J., DHIR, R.K., "Establishing a relationship between modulus of elasticity and compressive strength of recycled aggregate concrete", https://doi.org/10.1016/j.jclepro.2015.10.064. Journal of Cleaner Production, v.112, pp. 2171-2186, Jan. 2016.

[38] SILVA, R.V., BRITO, J., NEVES, R., et al. "Carbonation behavior of recycled aggregate concrete", https://doi.org/10.1016/j.cemconcomp.2015.04.017. Cement and Concrete Composites, v. 662, pp. 22-32, Sep. 2015.

[39] SILVA, S.R., ANDRADE, J.J., "Investigation of mechanical properties and carbonation of concretes with construction and demolition waste and fly ash", https://doi.org/10.1016/j.conbuildmat.2017.07.143.

Construction and Building Materials, v.153, pp. 704-715, Oct. 2017. 
[40] SINGH, N., SINGH, S.P., "Carbonation and electrical resistance of self-compacting concrete made with recycled aggregates and metakaolin", https://doi.org/10.1016/j.conbuildmat.2016.06.009. Construction and Building Materials , v.121, pp. 400-49 Sep. 2016.

[41] SPRAGG, R.P., CASTRO, J., NANTUNG, T., et al. "Variability analysis of the bulk resistivity measured using concrete cylinders", https://doi.org/10.1520/ACEM104596. Advances in Civil Engineering Materials, v. 1, pp. 1-17, April 2012.

[42] TAM, V.W.Y., GAO, X.F., TAM, C.M., "Microstructural analysis of recycled aggregate concrete produced from two-stage mixing approach", https://doi.org/10.1016/j.cemconres.2004.10.025. Cement and Concrete Research, v. 35, pp. 1195-1203, June 2005.

[43] TAM, V.W.Y., TAM, C.M.; WANG, Y., "Optimization on proportion for recycled aggregate in concrete using two-stage mixing approach", https://doi.org/10.1016/j.conbuildmat.2006.05.040. Construction and Building Materials, v. 21, pp. 1928-1939, Oct. 2007.

[44] TOPCU, L.B., GUNCAN, N.F., “Using waste concrete as aggregate”, https://doi.org/10.1016/00088846(95)00131-U. Cement and Concrete Research, v. 25, pp. 1385-1390, Oct. 1995.

[45] United States Environmental Protection Agency (EPA) (2018) Advancing Sustainable Materials Management: 2015 Fact Sheet. Washington DC: United States. https://www.epa.gov/sites/production/files/201807/documents/2015_smm_msw_factsheet_07242018_fnl_508_002.pdf

[46] VAZQUEZ, E., Progress of Recycling in the Built Environment. RILEM TC 217-PRE. Switzerland: RILEM Publishing, 2012. 10.1007/978-94-007-4908-5

[47] WANG, Y., NANUKUTTAN, S., BAI, Y., et al. "Influence of combined carbonation and chloride ingress regimes on rate of ingress and redistribution of chlorides in concretes",

https://doi.org/10.1016/j.conbuildmat.2017.02.121. Construction and Building Materials, v.140, pp. 173-183, June 2017.

[48] WIJAYASUNDARA, M.,MENDIS, P., CRAWFORD, H., "Integrated assessment of the use of recycled concrete aggregate replacing natural aggregate in structural concrete",

https://doi.org/10.1016/j.jclepro.2017.10.301. Journal of Cleaner Production, v. 174, pp. 591-604, Feb. 2018.

[49] XIAO, J., LI, W., FAN, Y., et al. "An overview of study on recycled aggregate concrete in China (1996-2011)", https://doi.org/10.1016/j.conbuildmat.2011.12.074. Construction and Building Materials, v. 32, pp. 364-383, June 2012.

[50] YANG, K., CHUNG H., ASHOUR, A.F., "Influence of type and replacement level of recycled aggregates on concrete properties",

https://www.researchgate.net/publication/283826633_Influence_of_type_and_replacement_level_of_recycle d_aggregates_on_concrete_properties. Materials Journal, v. 105, pp. 289-296, Mayo 2008.

[51] YU, A.T.W., POON, C.S., WONG, A., et al. "Impact of construction waste disposal charging scheme on work practices at construction sites in Hong Kong”, https://doi.org/10.1016/j.wasman.2012.09.023. Waste Management, v. 33 pp. 138-146, jaueary 2013.

\section{ORCID}

Carolina Shimomura Nanya

Fernanda Giannotti da Silva Ferreira

Valdirene Maria da Silva Capuzzo https://orcid.org/0000-0002-7515-8844

https://orcid.org/0000-0003-3222-1388

https://orcid.org/0000-0001-6923-7565 